\title{
The Moderating Effect of Perceived Organizational Support in Relationship between Affective Commitment and Workforce Agility in Workplace
}

\author{
Inggil Sholata Sya ${ }^{1}$ and Wustari Mangundjaya ${ }^{2}$ \\ Inggil.s.sya@gmail.com¹ and wustari@gmail.com ${ }^{2}$ \\ Faculty of Organizational and Industrial Psychology Universitas Indonesia ${ }^{1}$ and Faculty of \\ Organizational and Industrial Psychology Universitas Indonesia ${ }^{2}$
}

\begin{abstract}
The purpose of this research was examining the role of perceived organizational support as a moderator in the relationship of affective commitment and workforce agility in the workplace. This study was specific respondents to permanent employees in the manufacturing industry. Participants in this study numbered 154 permanent employees at one company. The researcher uses convenience sampling. This study adopted three instruments: perceived organizational support survey with 15 items, affective commitment questionnaire with 6 items, and 39 items of workforce agility questionnaire. Using regression, perceived organizational support as a positive moderator of the relationship between affective commitment and workforce agility in the workplace $(\mathrm{r}=.27, \mathrm{p}<0.05)$. Some recommendations made are that management should improve employees related to being emotionally attached, having the same identification with the organization, and involving the organization's activities and management should support employees by providing supervisory support; reward and job conditions; and perceived fairness.
\end{abstract}

Keywords: Perceived organizational support, affective commitment, and workforce agility.

\section{Introduction}

Early in the 21st century, companies facing the phenomenon of difficulties, ambiguity [1], turbulent environment and turbulence due to tight competition, rapid technological changes, shorter product life cycles as desired, trending trends, and buyer demand the more specialized product increases [2] in terms of price, specifications, quality, quantity and delivery [3]. According to Zhang [4], to be able to maintain the founding of a company, they must save a dynamic and competitive business environment. Globalization has entered a new era called the Industrial Revolution 4.0. Klaus [5]. The Fourth Industrial Revolution states that the world has undergone four stages of revolution, namely: 1) Industrial Revolution 1.0 occurred in the 18th century through the invention of steam engines, so that goods could be mass-produced, 2) Industrial Revolution 2.0 occurred in the 19-20th century through the use of electricity that makes production costs cheap, 3) the Industrial Revolution 3.0 occurred around the 1970s through the use of computerization, and 4) the Industrial Revolution 4.0 itself occurred around the 2010s through intelligence engineering and the internet of things as the backbone of human movement and connectivity and engine. Revolution 4.0 was also marked by the high 
turmoil of the VUCA era, the talent needed is those who have Agile, Assertive, Persistance, Collaborative and Continuous to learn, unlearn and relearn competencies.

In 1991, researchers introduced the concept of agility as a way to change the environment. The results showed that agility proved to be a strategic asset for the company [6]. Rapid response moves change needed agile organizations can adapt all elements of the company such as goals, technology, organizations, and people into unexpected changes [2]. Integration between businesses and employees will be directed at business growth that can be supportive and unexpected changes in competitive markets. Muduli [7] emphasizes that agile organizations cannot be achieved because labor agility is not the main for creating organizational agility. In general, there is still little research that discusses the agility of the workforce is still being debated. According to Chonko and Jones in Alavi \& Wahab [8], and agile employee exhibits two important behaviors (1) employees are able to react and adapt appropriately and timely to changes and (2) employees have the ability to take advantage of changes and turn them into benefits for the company.

In this study, workforce agility is considered as agile performance behavior in the workplace that can be observed, not personality, inclination, or attributes. If workforce agility behavior is not considered in the management program, the company will find it difficult to achieve agile behavior for its employees [9]. Some researchers find that several factors influence the formation of workforce agility in employees, e.g. information sharing, training, reward, power-sharing, workforce management practice [8], work organization [10] and organizational commitment [11]. A strong commitment from employees towards the organization where they work is needed by the organization to be able to contribute more to the organization's existence. Organizational commitment is illustrated by the strong belief of employees in accepting organizational goals and values, willingness to put forth sufficient effort for the organization, and a strong desire to maintain membership in the organization [12]. Allen and Meyer [13] explain that organizational commitment is divided into affective commitment, normative commitment, and continuance commitment. Affective commitment is a commitment that arises because of strong emotions between employees and the organization. Continuance commitment is a commitment that arises because of rational considerations such as the loss of welfare facilities if leaving the company. Normative commitment is a moral responsibility to continue to survive in the organization. Furthermore, this study discusses the focus on affective commitment and workforce agility. Limited research resources that discuss the relationship of affective commitment with workforce agility.

Numerous studies have thus been devoted to the antecedents of affective organizational commitment. Among these antecedents, perceived organizational support was found to have the strongest positive relationship with affective organizational commitment [14]. Eisenberg et al [15] state that POS is an overall belief developed by employees about the extent to which companies value their contribution and care for their welfare. This relates to the extent to which companies meet their wellbeing. POS is believed to grow the responsibility to support the organization to realize its goals [16], POS reduces work pressure, and improves work performance [17].

Over the past few decades, social exchange theory has become an approach that can explain the relationship between perceived organizational support and affective organizational commitment in terms of the process of social exchange. Organizational support theory states that organizational support achieved increases affective organizational commitment by creating an obligation to maintain organizational well-being and help it achieve its goals [18]. Empirical evidence has supported the view that reciprocal processes and social exchange are at the core of this relationship [16]. Perceived organization support can aid or hamper these 
variables' relationship because an employee has good affective commitment may not agile if they are not gotten support from organization. There is no previous research that explains the relationship and mechanism between variables. Figure 1 indicates the model of this study.

\section{Research Hypothesis}

Following hypothesis was tested during the study

H1: Affective commitment is positively related to workforce agility

H2: Perceived organizational support moderates the relationship between affective commitment and workforce agility

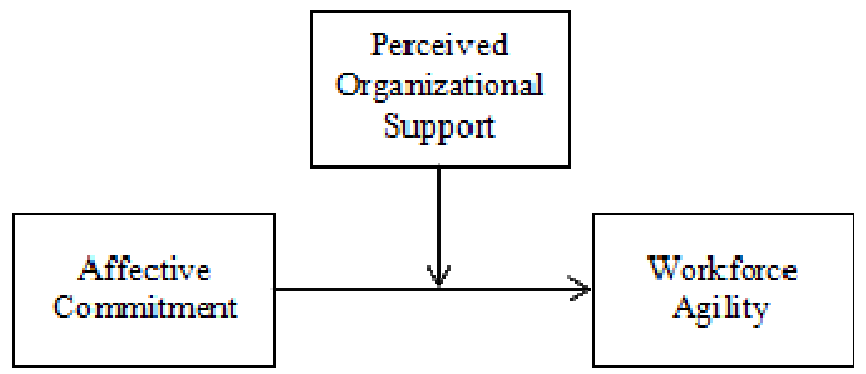

Fig. 1. Model Study

\section{Method}

\subsection{Research design and procedure}

Testing the research hypothesis using a quantitative method, in the form of a cross-sectional design using Workforce Agility Questionnaire (WAQ), Survey of Perceived Organizational Support (SPOS), and Affective Organizational Commitment Questionnaire (AOCQ). Researchers used a sampling technique with convenience sampling method [19]. Data obtained through online questionnaires (the online website-hosted survey, google form) and hardcopy questionnaires. Researchers also hand out a paper-based questionnaire to 154 copies were completed.

\subsection{Measurement instruments}

This research using three instruments that consist of 60 items. The Cronbach alpha for WAQ, SPOS, and AOCQ in this study were $0.84,0.83,0.89$ respectively, which demonstrated high reliability for every three instruments. The analysis of the data was performed in PROCESS macro model 3 Hayes, using SPSS 25 statistical software. The sets of measures described below were presented to this research.

\subsection{Workforce agility}

The Workforce Agility Questionnaire (WAQ) used in this study was adapted and modified by the researcher. The workforce agility questionnaire was developed by Sherehiy et al. [20] by classifying workforce agility attributes into three main abilities namely proactivity, adaptability and resiliency. The questionnaire consisted of 39 items that were measured using a 6-point Likert scales that had a score range from 1 (strongly disagree) to 6 (strongly agree). WAQ has 29 positive items (favorable) and 10 negative items (unfavorable). 


\subsection{Perceived organizational support}

The questionnaire used by the researcher is the Survey of Perceived Organizational Support (SPOS) which was adapted and modified based on Eisenberger's development theory [21] consisting of 15 item statements with a 6-point Likert scales that range from point 1 (strongly disagree) to with 6 (strongly agree). The items in SPOS consist of 3 factors forming the perception of organizational support, namely supervisor support, organizational rewards, and favorable job conditions and fairness.

\subsection{Affective commitment}

Affective commitment is measured by using 6 items Affective Organizational Commitment Questionnaire (OCQ) questions that are adapted and modified based on organizational commitment theory from Meyer \& Allen [22]. Affective commitment consists of three favorable items and 3 unfavorable items. Participants choose one of the 6-point Likert scales which has a range from point 1 (strongly disagree) to 6 (strongly agree).

\subsection{Data analysis}

The model in Figure 1 used conditional process modeling to test for moderation outlined by Baron and Kenny using regression SPSS 25.0. Baron and Kenny stated that a moderator hypothesis is supported if the interaction or the product of a predictor variable and the moderator is significant when the predictor and the moderator were being controlled [23]. The hypothesized model tested to see whether perceived organizational support moderated the relationships among affective commitment and workforce agility.

\subsection{Participants}

The statistical population consists of 300 permanent employees from a manufacturing industry in Indonesia. This study was specific respondents to permanent employees in the manufacturing industry because manufacturing companies are dynamic companies following changes in the environment and customer demand. The researcher uses convenience sampling. Out of 300 questionnaires, the researcher received 154 completed questionnaires.

\section{Result}

\subsection{Descriptive statistics and correlations}

Of 154 participants, the male was $85.1 \%$. Education range for the sample included bachelor degree (45.5\%), high school graduate (35.7\%), and diploma degree (18.8\%). Participants was $56.5 \% \mathrm{Y}$ generation (1961-1980) and $43.5 \% \mathrm{X}$ generation (1981-2000). These tenure in the current organization were categorized into establishment stage (9.74\%), advancement stage $(35.06 \%)$, and maintenance stage (55.20\%). Table 1 indicates means $(\mathrm{M})$, standard deviation (SD), and Pearson correlation (r) for all variables. The strength and direction of the linear relationship between the variables can be described by correlation analysis. It has a significant correlation among the constructs. Baron and Kenny (1986) state that if the research has significant correlation among constructs, the researcher can propose mediation analysis. 
Table 1. Mean, Standard Deviation, Correlation

\begin{tabular}{clccccc}
\hline No. & \multicolumn{1}{c}{ Dimensi } & M & SD & 1 & 2 & 3 \\
\hline 1 & Perceived Organizational Support & 4.10 & 0.66 & 1 & & \\
2 & Affectice Commitment & 4.49 & 0.81 & $.64^{* *}$ & 1 & \\
3 & Workforce Agility & 4.50 & 0.48 & $.43^{* *}$ & $.48^{* *}$ & 1 \\
\hline
\end{tabular}

** Correlation is significant at the 0.01 level (2-tailed).

\subsection{Model Testing}

In Table 2, study 1 showed the direct influence of affective commitment on workforce agility. It indicated that affective commitment was a critical factor in workforce agility. The $\mathrm{R}^{2}$ was .226. In other words, this affective commitment explained only $22.6 \%$ of the variance in workforce agility. The overall regression model was significant $\left(\mathrm{R}^{2}=.226, \mathrm{~F}\right.$ change $=44.46$, $p<.005)$. From the individual coefficients, affective commitment $(\beta=.48)$ was also significant. In study 2, the researcher analyzes the interaction of affective commitment and perceived organizational support. The results of this study have $t=2.85$ which means the role of perceived organizational support moderation will strengthen the relationship of affective commitment and workforce agility at work. That is, the higher the perceived organizational support of employees, the stronger the relationship of affective commitment will be to the agile of employees at work. Conversely, if employees have low perceived organizational support levels, then it does not strengthen the relationship of affective commitment to workforce agility. This showed that the perceived organizational support explained an additional $29.1 \%$ of the variance in workforce agility, after controlling affective commitment $\left(\mathrm{R}^{2}=29.1\right.$, Fchange $\left.=20.520, p<.005\right)$.

Table 2. Results of hierarchical regression on workforce agility

\begin{tabular}{|c|c|c|c|c|c|c|}
\hline Model & $\beta$ & SE & $\mathrm{t}$ & $\mathrm{R}^{2}$ & $\mathrm{~F}$ & $p$ \\
\hline Study 1 & .48 & .42 & 6.67 & .22 & 44.46 & .00 \\
\hline Study $2($ Int 1$)$ & 1.88 & .40 & 2.85 & .29 & 20.52 & .00 \\
\hline
\end{tabular}

\section{Discussion}

Based on the results of the study, the perception of organizational support moderates the positive relationship of affective commitment and workforce agility. Specifically, the study has made a discovery that the higher the employee perceives that the organization supports it by paying attention to employee welfare, it will improve employee emotional relationships in the company in this case in the form of affective commitment and improve employee workforce agility to be adaptive and flexible in dealing with changes that occur in the organization. Agile employee attitude will help employees to provide innovation for the organization. According to Muduli [7], workforce agility is a collection of organized and dynamic talent that can quickly provide the right skills and knowledge at the right time to meet the business needs of problem-solving. An agile workforce is a flexible trained workforce that can adapt quickly and easily to offer solutions to take advantage of new opportunities. It also supports social exchange theory which states that perceived organizational support increases affective organizational commitment by creating an obligation to maintain organizational well-being and help it achieve its goals [18]. 


\section{Conclusion}

This research can explain that after taking data on 154 permanent employees, the affective commitment is positively related to workforce agility and there is moderating effect of perceived organizational support in the relationship between affective commitment and workforce agility in a manufacturing industry. It implies that the employee commitment and workforce agility can be improved through improving the perceived organizational support.

\section{Recommendation}

Based on finding, the following recommendations are hereby suggested:

Further research is still needed to increase knowledge in the field of workforce agility in Indonesia. Also besides, there needs to investigate the effect of differences in each dimension on the perception of organizational support for the relationship between affective commitment and workforce agility using the SEM model to see the relationship in more detail.

On practical implication, workforce agility has a strong relationship with affective commitment. It seems essential that management should facilitate employee training, fairness, empowerment, and compensation to improve the employee's emotional attachment, employee identification with organization and employee's involvement with the organization's activities. Last, management should support the employee, build perceived fairness and reward to increase their perceived organizational support. 



\section{References}

[1] Azuara, A.V.: A human resource perspective on the development of workforce agility. Master's Thesis School of Business and Management Pepperdine University. (2015)

[2] Sherehiy, B., \& Karwowski, W.: The relationship between work organization and workforce agility in small manufacturing enterprises. International Journal of Industrial Ergonomics. Vol. 44, pp. 466-473. (2014).

[3] Al-Mahmeed, G.A.: Investigating the mediating role of workforce agility on the effect of lean six sigma elements on competitive advantage "a comparative study among royal bahraini armed forces". Master's Thesis Middle East University. (2018)

[4] Zhang, D. Z.: Towards theory building in agile manufacturing strategies "case studies of an agility taxonomy". International Journal of Production Economics. Vol.131, pp. 303-312. (2011).

[5] Shwab, K.: The Fourth Industrial Revolution. New York: Crown Business. (2016).

[6] Breu, K., Hemingway, C.J., Strathern, M., \& Bridger, D.: Workforce agility: the new employee strategy for the knowledge economy. Journal Information Technology. Vol. 17, pp. 21-31. (2001)

[7] Muduli, A.: Exploring the facilitators and mediators of workforce agility: an empirical study. Management Research Review. Vol. 39, pp. 1567-1586. (2001)

[8] Alavi, S. \& Wahab, D. A.: A review of workforce agility. Journal of Applied Scienciesn, Engineering and Technology. Vol. 5, pp. 4195-4199. (2013).

[9] Chonko, L.B. \& jones, E.: The need for speed: agility selling. Journal of Personal Selling \& Sales Management. Vol. 25, pp. 371-382. (2005).

[10] Sherehiy, B.: Relationships Between Agility Strategy: Work Organization and Workforce Agility. ProQuest, $\quad$ pp: 152, ISBN: 0549548181, Retrieved from:http://books.google.com.pk/books/about/Relationships_Between_Agility_Strategy_W.html?i $\mathrm{d}=$ nWve3mv3EGEC\&redir_esc $=$ y. (2008).

[11] Aidan, Z., Alibabaei, A., \& Mohammad, H.S.: Identify the Relationship between Employer Brand Attractiveness, Job Satisfaction, Organizational Commitment and Workforce Agility in Telecom Industries based on Structural Equation Modeling (SEM) (Case Study: Huawei Technologies Service Iranian). (2018).

[12] Mowday, R.T., Porter, L.W., \& Steers, R.M.: Employee organization linkages:the psychology of commitment, absenteeism, and turn over. Acadmeic press. (2018).

[13] Allen, N. J. \& Meyer, J. P.: The measurement and antecedent of affective, continuance and normative commitment to organizational. PT Elex Media Komputindo, Jakarta. (2013).

[14] Marique, G., Stinglhamber, F., Desmette, D., Caesens, G., \& Zanet, F.D.: The relationship between perceived organizational support and affective commitment: a social identity perspective. Group \& Organization Management. Vol. 38, pp. 68 -100. doi: 10.1177/1059601112457200. (2012).

[15] Raudha, U.: Meningkatkan persepsi dukungan organisasi dan kepuasan kerja karyawan melalui rangkaian program coaching. Master's Thesis Industrial and Organizational Psychology. (2016).

[16] Eisenberger, R., Armeli, S., Rexwinkel, B., Lynch, P. D., \& Rhoades, L.: Reciprocation of perceived organizational support. Journal of Applied Psychology, Vol. 86, pp. 42-51. doi:10.1037/0021-9010.86.1.42. (2001).

[17] Rhoades,L. \& Eisenberger, R.: Perceived organizational support: A review of literature. Journal of applied psychology, Vol. 87, pp. 698-714. doi: 10.1037//0021-9010.87.4.698. (2002).

[18] Rhoades, L., Eisenberger, R., \& Armeli, S.: Affective commitment to the organization: The contribution of perceived organizational support. Journal of Applied Psychology, Vol. 86, pp. 825836. doi:10.1037/0021-9010.86.5.825. (2001).

[19] Gravetter, F. J., \& Forzano, L.: Research methods for the behavioral sciences 4th Edition. Canada: Wadsworth Pub. (2012).

[20] Alavi, S., Wahab, D. A., Muhamas, N., \& Srihani, B.A.: Organic structure and organisational learning as the main antecedents of workforce agility. International Journal of Production Research: 1-22. (2014).

[21] Santoso, A. R. Workshop coaching atasan untuk meningkatkan persepsi pegawai terhadap dukungan atasan dan komitmen afektif untuk berubah. Universitas Indonesia. (2018). 
[22] Meyer, J. P., \& Allen, N. J.: Commitment in the Workplace. Thousand Oak, CA: Sage Publication Inc. Pp. 118-119. (1997).

[23] Ekpe, I., Ikechukwu, A.E., Adelaiye, M.O., Adim, V.: The moderating effect of self-motivation on the relationship between parent's socio-economic background and children's academic performance at nigerian universities. Asian Social Science, Vol. 10, pp. 73-79. (2014) 